\title{
The origin of language
}

\section{Symbiosism and symbiomism}

\section{George van Driem \\ Leiden University}

Symbiosism is a Darwinian model of language and its emergence. Symbiotic Theory operates on the Leiden definition of memes as isofunctional

neuroanatomical entities corresponding to linguistic signs in the Saussurean sense, not on the Oxonian conception of memes as units of imitation. Symbiosism treats linguistic forms as vehicles for the reproduction of meaningful elements in the hominid brain and so transcends the obsolete discord between the functionalist or European structuralist conception of language, whereby linguistic forms are seen as instruments used to convey meaningful elements, and the formalist or generative approach, whereby linguistic forms are treated as abstract structures which can be filled with meaningful elements. Symbiomism is the philosophy of life which grew out of Symbiosism and which understands our individual and collective human identity as symbiomes of a biological host and a semiotic symbiont.

Alfredo Trombetti's 'la nostra dottrina monogenistica' (1925: 151) was, as I once previously hastened to point out, precisely that, a doctrine, because demonstrating that all human languages stem from a single original mother tongue lies beyond the bounds of what is accessible to empirical testing, at least by conventional comparative linguistics. Allan Bomhard, Michael Fortescue, Joseph Greenberg, Laurent Sagart and the late and universally beloved Sergei Starostin have gone beyond where many traditional comparative linguists dare to tread and so ventured through what I have characterised epistemologically as the 'monogeneticist time warp' (van Driem 2001: 145). Yet the work of these intrepid scholars - but perhaps first and foremost amongst them, Harold Fleming - has shown that it may be possible to breach this time warp in an empirically defensible way and so responsibly to indulge in 'gazing beyond the event horizon' of conventional comparative linguistics.

This essay too goes well beyond this horizon and treats of the origin of language itself. The empirical basis of the Leiden conception of language is language's own lingering legacy in the shape of the very neuroanatomical and semiotic workings of meaning. Yet the aim here is not to repeat what has been explained in the previous work of exponents of the Leiden school of language evolution, but to point out an essential difference between Kortlandt's and Wiedenhof's views of language and my 
own, viz. Kortlandt $(1985,1998,2003)$, Wiedenhof (1996) vs. van Driem (2001a, $2001 b, 2003,2004,2005)$. Some critics had already noticed that the Leiden school is not a single coherent view of language evolution, but three coherent views of language evolution, albeit largely congruent ones.

Symbiosism is a Darwinian model of language and its emergence. Symbiosism is a variety of Symbiotic Theory, which treats linguistic forms as vehicles for the reproduction of meaningful elements in the hominid brain. The symbiotic view transcends the obsolete discord between the functionalist or European structuralist conception of language, whereby linguistic forms are seen as instruments used to convey meaningful elements, and the formalist or generative approach, whereby linguistic forms are treated as abstract structures which can be filled with meaningful elements. Symbiotic Theory shows naming and syntax to be two faces of the same phenomenon.

Syntax arose from meaning. The first primaeval holistic utterances with a meaning in the linguistic sense inherently constituted a projection of reality with a temporal dimension. First-order predication arose when such a holistic utterance was split. This point of view was argued by Pierre de Maupertuis (1756, III: 444) and Hugo Schuchardt (1919a, 1919b) and contrasts with the naïve view that syntax arose from the concatenation of labels or names. The splitting of a signal for 'The baby has fallen out of the tree' could have yielded meanings such as 'That which has fallen out of the tree is our baby' and 'What the baby has done is to fall out of the tree'. Mária Ujhelyi (1998) has considered long-call structures in apes in this regard.

Moreover, Symbiotic Theory operates not on the Oxonian conception of a meme as a 'unit of imitation', but on the Leiden definition of memes as isofunctional neuroanatomical units corresponding to linguistic signs in the Saussurean sense, corresponding to single morphemes or monomorphemic words. The neuronal correlate of a meaning along with the neuronal representation of its associated phonological form or grammatical manifestation is a meme, whereas in Leiden school terminology a unit of imitation is a mime. The symbiotic model of the human mind is based on an understanding of language as a semiotic organism which has arisen and evolved in the hominid brain. The empirical basis of the Leiden conception of language is language's own lingering and tangible evolutionary legacy in the shape of the neuroanatomical and semiotic workings of meaning.

The Leiden school is not a single view of language evolution, but three largely congruent views of language evolution. Kortlandt $(1985,1998,2003)$ and Wiedenhof (1996) conceive language to be a parasite, based on the correct insight that natural meanings have the properties of non-constructible sets in the mathematical sense. Symbiosism, however, distinguishes the mutualist nature of language as such from the workings of individual meanings (van Driem 2001a, 2001b, 2003, 2004, 2005). Language has greatly augmented our reproductive fitness to the detriment of countless other macroscopic species. Language, therefore, is a mutualist symbiont.
Our language-driven pre-eminence has made us the blight of the biosphere in the Holocene period. On the other hand, language-borne ideas can be beneficial or deleterious to the human host.

\section{Language as organism is no mere metaphor}

The idea that language is a life form in its own right was popular amongst Indo-European linguists in Germany in the early 19th century. Friedrich von Schlegel described language as 'ein lebendiges Gewebe' (1808: 64), and Wilhelm von Humboldt spoke of the 'Organismus der Sprache' (1812: 8). Later, inspired by Ernst Haeckel's popularisation in Germany of Darwin's 1859 book On the Origin of Species, August Schleicher formulated a lucid statement on the organismal nature of language. Some have misinterpreted this conception of language as an organism as no more than a metaphor. Yet Schleicher's statement about language as a life form was unequivocally literal: 'Die Sprachen sind Naturorganismen, die, ohne vom Willen des Menschen bestimmbar zu sein, entstunden, nach bestimmten Gesetzen wuchsen und sich entwickelten und wiederum altern und absterben; auch ihnen ist jene Reihe von Erscheinungen eigen, die man unter dem Namen »Leben « zu verstehen pflegt' (1863: 6-7).

The conceptualisation of language as an organism remained popular, but the notion was reinterpreted by historical and comparative linguists in ways that differed from the intimations of more semiotically inclined thinkers. In retrospect, the latter category of thinkers blazed the trail for the Leiden school of language evolution. The indologist Max Müller and later the mathematician Bertus Brouwer had profound and often disturbing insights into the nature of linguistic meaning and the effects of language. Müller and Brouwer can be identified as Frederik Kortlandt's intellectual precursors. In the early 1980s, Kortlandt's tutorials led to the growth in Leiden of a new school of thought on language evolution, with Jeroen Wiedenhof and myself at the time as his principal disciples. His now famous article on the language parasite, which appeared in 1985, explained that the nature of the organism stemmed from the fact that meanings, the replicating units of language, were non-constructible sets in the constructivist mathematical sense.

Kortlandt's view was a radical departure from earlier views on language as an organism, for his semiotic approach cut to the chase in identifying meaning and its behaviour as the crux of linguistics and language evolution. In Kortlandt's Leiden school the inherently dynamic character of meanings is seen as a direct function of their neuroanatomy, as modelled by Hebb (1949) and later elaborated by Changeux (1983) and Edelman (1987). Brouwerian semantics dovetails with neuroanatomical reality and the observable behaviour of categories of meaning as units in the Darwinian process of neuronal group selection. 
The Leiden model heralds a revolution in the way we think about ourselves. So one might predict a natural disinclination to welcome Symbiotic Theory based on what we know about human nature or, alternatively, based on the historiographical model of paradigm shift in scientific revolutions developed by Thomas Kuhn $(1962,1977)$ Kuhn underscored the social dimensions and psychological imperatives of change, though it would be imbalanced to overlook the role of sheer serendipity in science and the individual character of insight in scientific thought. Some have taken cognizance of, but chosen to ignore Symbiotic Theory, whilst Salverda (2003) has drawn attention to several attempts to surreptitiously scoop the Leiden school by secondarily promulgating its insights. Another, intrinsically far more intriguing cause for a reluctance to accept the symbiotic view, I believe, may lie in a natural resistance built into our minds against recognising the linguistic symbiont for what it is. Language may not want to be found out. Our mind, caught in the web of language, is neither inclined nor even wellequipped to discern its own linguistic soul.

\section{Pessimistic vs. optimistic linguistics?}

The perceived difference between Kortlandt's view of language and my own symbiosist view has often been phrased, even by Kortlandt himself, along the lines of the master viewing language as a parasite, whereas his pupil sees language as a symbiont. Part of the confusion is terminological in nature, for technically a parasite too is a symbiont. Symbiosis is when two phylogenetically distinct organisms live together in some sort of intimate relationship. Symbiotic relationships abound in nature and take on many forms. The most far-reaching form of symbiosis is a relationship in which both organisms cannot live without the other and effectively become as one life form. Most life forms on the planet today originated as symbiotic relationships. An early understanding of the role of symbiosis in evolution dates back to the same period in the history of biology that evolution by natural selection first came to be understood by Charles Darwin and Alfred Russel Wallace.

Pierre Joseph van Beneden, professor at the Catholic University at Leuven, adopted the term mutuellisme, brandished by the French social reformer Pierre-Joseph Proudhon for his ostensibly benign variety of communism, to apply to mutually beneficial relationships between species. The Belgian marine biologist later popularised the idea in his 1876 book Les commensaux et les parasites, which also appeared in German and English translations that same year. He distinguished various types of symbiotic relationship, i.e., parasite, free-living commensal, resident or obligate commensal and mutualist. Van Beneden stressed that beneficial reciprocity was as prevalent as commensalism. He described in detail how commensalism and mutualism contrasted strongly with the deleterious effects of parasitism and likewise carefully distinguished between various forms of commensalism and the intimate and reciprocally beneficial interdependency which characterised mutualism.

Van Beneden's work inspired the German botanist Heinrich Anton de Bary, who in 1879 popularised the word Symbiose 'symbiosis', an already extant term of Greek origin, in a public address to German biologists and physicians at Cassel as a cover term to designate all forms of 'Zusammenleben ungleichnamiger Organismen', i.e., the living together of organisms with different names, viz. belonging to differently named taxa. Symbiosis included 'der vollständige Parasitismus' (viz. full-fledged parasitism, which de Bary held to be the 'most exquisite' form of symbiosis), various types of commensals, and 'van Beneden's Mutualisten', which were neither parasitic nor commensal. De Bary's most fascinating examples were lichens. All lichens are symbiomes of fungi known as ascomycetes with either algae or cyanobacteria. His description of these fascinating symbiomes made lichens the emblematic classroom example of symbiosis.

Friedrich Schmitz, professor of botany in Bonn, observed that the chloroplasts of eukaryotic algae, along with their associated starch-accumulating structures called pyrenoids, were not fabricated anew in the cytoplasm, but reproduced independently by division within individual cells (1882). Schmitz first made this observation in 1880 'für eine Anzahl von Algen ... während eines Aufenthaltes an der Zoologischen Station zu Neapel, but within two years he had established that the independent reproduction of Chromatophoren or chloroplasts was a feature of all eukaryotic algae.

This observation regarding the autonomous nature of chloroplasts in eukaryotic algae inspired botanist Andreas Schimper, who in 1883 showed that Chlorophyllkörner or chloroplasts in green plants too 'nicht durch Neubildung aus dem Zellplasma, sondern durch Theilung aus einander entstehen' (1883: 106). This discovery led Schimper to venture that all green plants had originated through an original symbiotic association of two unlike organisms: 'Möglicherweise verdanken die grünen Pflanzen wirklich einer Vereinigung eines farblosen Organismus mit einem mit Chlorophyll gleichmäßig tingierten ihren Ursprung.' In a similar vein, the botanist Albert Bernard Frank (1885) soon afterwards recognised mycorrhiza too to be a symbiotic relationship between terrestrial plants and subterranean fungi which subsist on their roots and provide these plants with essential nitrogen and minerals.

1. Recently, gene sequencing has provided the first genomic evidence that all plastids form a monophyletic group and that a single endosymbiotic event gave rise to a unified but highly diverse phylum comprising all primary photosynthetic eukaryotes, viz. green plants, red algae and glaucophytes (Rodríguez-Ezpeleta et al. 2005). 
It was in Russia that the term symbiosis began to acquire a new anodyne flavour. Andrej Sergeevič Famintsyn studied the ontogeny of chloroplasts in green plants $(1889,1893,1907)$. His studies inspired Constantin Mereschkowksy to make the same observation in 1905 that Schmitz had made in 1880 and Schimper in 1883, namely that chloroplasts are not assembled from scratch in the cytoplasm, but are cytoplasmically inherited and replicate themselves autonomously within the host cell. Mereschkowks went a step further than Schmitz and Schimper, however, in claiming that chloroplasts remained genetically independent of the nucleus. Mereschkowksy also argued that 'Cyanophyceae' or cyanobacteria, which until relatively recently used to be called blue-green algae, were basically free living chloroplasts that had not entered into the cytoplasma of a host cell, where they had taken up a reduced symbiotic existence and rendered the host cell autotrophic. For the genesis of a new life form through symbiosis, Mereschkowsky coined the term symbiogenesis in 1909.

Famintsyn felt that the term simbioz" should be reserved for relationships that were mutually beneficial, i.e., that simbioz" be used in the sense of van Beneden's mutualism rather than in the sense of de Bary's symbiosis. Famintsyn's symbiosi therefore excluded parasitism, which de Bary had considered to be the 'most exquisite' form of symbiosis. Since then, numerous types of symbiosis have been identified and analysed, and an elaborate terminology has evolved to designate different types of symbiotic relationship, e.g., parasymbiosis, social parasymbiosis, phoresy, inquilinism, symbiotrophism (Henry 1966; Margulis \& Schwartz 1988). This rich arsenal of precise terminology contrasts with the feel-good 'New Age' flavour which the term symbiosi has acquired today in popular lay usage. Not all symbiotic relationships are mutually beneficial, but in lay parlance and even sometimes in biological discourse symbiosis is used to refer to mutually beneficial relationships. This connotation can be traced back to Famintsyn, who gave the term a favourable twist and thus set in motion a shift in meaning away from de Bary's original usage of Symbiose as a cover term for all forms of intimate inter-species relationship.

Recapitulating, the label 'Symbiotic Theory', which I introduced for the Leiden model of language evolution, can be applied to both Kortlandt's view of language and my own. Besides using the term symbiosis strictly in its original Flemish and German sense, i.e., free of value judgment, I have discussed the language organism whilst knowingly suggesting the originally Russian, now popular pleasant connotation of symbiosis as mutualism. Kortlandt, however, has insisted that language is a parasite. A terminologically more precise rephrasing of the difference between Kortlandt's view of language and mine, therefore, would be whether language is a parasite, and thus an organism deleterious to its hominid host, or a mutualist, and so a partner in a mutually beneficial symbiotic relationship. Kortlandt has called his version of Symbiotic Theory 'the parasitologist's view'. I call my more optimistic, mutualist view Symbiosism. Yet we must be careful not to over-simplify either view.

\section{The Leiden definition of the meme and its precursors}

An idea often takes shape in more than just one human brain. Sometimes the same idea occurs independently to the minds of different individuals at very different times or even recurrently to various people throughout history. Alternatively, the cultural environment may be ripe for an idea which occurs independently to the minds of different individuals at roughly the same time in history. Yet scholars seldom recount the course of events in precisely that way, and the history of ideas is usually told as a tale that does not reflect this more complex reality. The view of culture as a dynamic evolving process in which words and ideas act as the transmitted units of evolution is in fact a rather obvious way of looking at human culture, and so this conception of culture has occurred to many people. Victor Hugo wrote that 'le mot, qu'on le sache, est un Être vivant' (1856, i: l. 675)

The linguist Friedrich Max Müller was a great proponent of evolution by natural selection and applied the theory to language, religion and cultural evolution. Müller wrote: 'A struggle for life is constantly going on amongst the words and grammatical forms in each language. The better, the shorter, the easier forms are constantly gaining the upper hand, and they owe their success to their inherent virtue' (1870:257). Darwin himself adopted Müller's view of linguistic evolution and echoed Müller's insights: 'The survival or preservation of certain favoured words in the struggle for existence is natural selection' (1871, I: 60-61). Darwin added 'novelty' to Müller's repertoire of traits that might enhance the appeal and thus survival potential of a word.

Writing in the context of the phylogeny of Niger-Congo languages, Gottlob Adolf Krause claimed: 'Für mich ist jedes Wort ein sprechendes Lebewesen, das seine Geschichte erzählt, sobald ich es kennengelernt habe. Ich sehe die Zeit kommen wo man von einer etymologischen Biologie sprechen wird' (1885: 257). So, already in the nineteenth century, words were conceived as the living units of cultural evolution by Hugo and Krause, and Müller and Darwin explicitly saw words as units of evolution subject to natural selection.

In a related but different vein, a zoologist in Germany began to contemplate the notion of transmissible neural entities. Richard Wolfgang Semon coined the term Mneme. Semon was born on the 22nd of August 1859 in Berlin. He became Ernst Haeckel's favourite student at Jena, conducted zoological expeditions to Africa and Australia, produced a number of zoological studies, converted from Judaism to Protestantism in 1885, and later became a Monist, all before he developed his mneme theory. Semon published the book Die Mneme als erhaltendes Prinzip im Wechsel des organischen Geschehens in Leipzig in 1904, two revised editions of which appeared in 1908 and in 1911. A first sequel to Die Mneme appeared in 1909 entitled Die mnemischen Empfindungen. Yet Semon never completed the second sequel about 'die Pathologie der Mneme'. Unable to reconcile himself with the defeat of Germany at the end of the 
First World War, he shot himself through the head on the 27th of December 1918. His lifeless body was found the following day sprawled out on the old black, white and red German tricolour. ${ }^{2}$

Deeply imbued with the work of Darwin and Haeckel, Semon's conception of the mneme was fundamentally an idea which modern biological theoreticians today would call Lamarckian. ${ }^{3}$ Semon developed an epigenetic theory of memory based on the notion of the Engramm, a modification in the neural tissues corresponding to a memory triggered by a Reiz 'stimulus'. Semon conceived of the mneme as the collective set of Engrammata or neural memory traces, whether conscious or subconscious, that he believed were inherited genetically. Semon describes the mneme as 'das für die organische Entwicklung unumgänglich notwendige erhaltende Prinzip, das die Umbildungen bewahrt, welche die Außenwelt fort und fort schafft' (1911: 407). Largely forgotten today, Semon's ideas were quite influential in the first half of the twentieth century, and some of his other coinages such as Engramm, Engraphie and Ekphorie have taken up lives of their own, in German as well as in other languages.

The term 'mneme' was adopted by the Belgian entomologist, poet and playwright Maurice Maeterlinck, whose work was preoccupied with symbolism and who won the Nobel prize for literature in 1911. His entomological works La vie des abeilles, first published in 1901, and La vie des termites, first published in 1926, were translated as The Life of the Bee and The Soul of the White Ant respectively. Both books went into numerous printings in English in the first half of the twentieth century. Maeterlinck attempted to explain the workings of memory in termites and ants in terms of engrams, i.e., neural memory traces, which were added 'upon the individual mneme' (1927: 198).

After the discovery of the double helical structure of deoxyribose nucleic acid (DNA) and the chemical identity of genes in the Cavendish lab in Cambridge by Francis Crick, James Watson and Rosalind Franklin in 1953, Müller's view of the natural selection of 'words and grammatical forms' and Darwin's view of 'the survival or preservation of certain favoured words' was rapidly and widely succeeded by a more general public awareness that there must be units of cultural replication analogous to the gene.

The cultural evolutionist Leslie White came up with the term symbolate for 'something that results from the action or process of symboling', coarsely conceived as encompassing all 'phenomena dependent upon symboling' (1959: 231, 246). Perhaps unbeknownst to White, the term symbolate had already been used by Lady Victoria Welby in

2. A more detailed account of his colourful and turbulent life in the historical and scientific context of the day is provided by Jürg Schatzmann (1968).

3. The neo-Darwinians have generally been wont to obscure or underplay the fact that Darwin himself was a Lamarckian. the sense of 'thing symbolised' (1896: 196). For White, however, symbolates were observable not only as acts and external events, but, in keeping with the inclusive definition of culture, symbolates also include 'concepts, beliefs, emotions, attitudes' within the human brain as well as acts and events mediated by 'symboling' and all external objects and events which are cultural artefacts or in some way the result of human intervention (1959: 235).

A widespread awareness that cultural evolution too must be a Darwinian process prompted Hudson Hoagland in 1962 to suggest what must have been obvious to many people. Hoagland proposed that ideas are the units of selection and that ideas may be considered to social evolution what genes are to biological evolution' (Huxley 1962: 203). Hoagland saw competing ideas as units of what he called 'psychosocial selection' in cultural evolution. In 1964, Henry A. Murray coined the term idene as an analogue in social evolution to the gene in biological evolution (Hoagland 1964: 111).

In 1963, manifestly inspired by the works of Semon and Maeterlinck, Harold Blum coined the term mnemotype for a unit of 'information determining the cultural pattern of a society' residing 'in the brains of its members where it is stored as personal sets of memory images. Blum envisaged the cultural evolution of a society in terms of 'changes in the collective mnemotype', and that these innovations were precipitated by 'changes in the individual mnemotypes which compose it' (1963: 39). Others likewise devised neologisms for the widely assumed unit of cultural selection. Ralph Burhoe coined the term culturetype for assemblages of cultural and linguistic information. He saw this as a new type of information in evolution representing a relatively stable, transmissible 'heritage' largely independent of the genotype, but just as subject to natural selection (1967: 83).

In a panoramic treatment of man's natural history, Carl Swanson (1973: 313) proposed the term socio-genes for the ideas or cultural molecules as units of selection in a process of cultural evolution governed by the principles of Darwin and Mendel. Swanson also addresses the subjective and illusory nature of 'progress' in biological and cultural evolution. In a similar vein, Cloak wrote of the 'natural selection of cultural things', such as behavioural instructions which he termed tuitions and defined as 'the programming of an instruction upon one's hearing a linguistic analogue of that instruction uttered by a conspecific', a process which 'is almost surely unique to humans' (1975: 167). Cloak described tuitions as 'corpuscules of culture' residing in the central nervous system.

Just as Maeterlink's mneme had been the inspiration of Blum's coinage mnemotype, Laurent (1999) identified Maeterlink's mneme as the source of Richard Dawkins' meme in 1976, although the Oxford zoologist may no longer have been consciously aware of the engram at the time. A meme as defined by Dawkins was not just something essentially different from Semon's Mneme. Dawkins' meme also differed from all the cultural replicators for which various labels had already been proposed, viz. words, symbolates, ideas, mnemotypes, idenes, culturetypes, socio-genes and tuitions. 
Whereas all these putative units of cultural selection were either explicitly or im plicitly conceived as linguistic or language-mediated entities, Dawkins characterise a meme as 'a unit of cultural transmission, or a unit of imitation', with italics supplied by Dawkins to emphasise that a meme was a unit of essentially imitative behaviour (1976: 206). As opposed to earlier views of the unit of cultural selection, Dawkins' meme was inspired as much by the mindless mimicry observed in butterflies and by learnt behaviours such as some bird song as it was by human culture. With its singleminded focus on imitation, a deafening silence reigned about the crucial role of language. In comparison to earlier conceptions of the units of selection in cultural evolution, the meme was originally therefore actually a step backward.

In a later edition, Dawkins brought his definition of the meme more into line with earlier conceptions of a unit of cultural selection by adding that a meme was 'a unit of information residing in the brain' (1982). Yet fundamentally Dawkins' meme remained a 'unit of imitation', and therefore something neither specifically human nor necessarily linguistic. This definition found its way into the Oxford English Dictionary as 'an element of a culture that may be considered to be passed on by non-genetic means, esp. imitation' The Oxonian meme is not essentially a semiotic construct. Blackmore, an orthodox proponent of Dawkins' view of the meme, envisages 'spoken grammatica language' as resulting from 'the success of copyable sounds' and explicitly denies the relevance of the meanings borne by language (1999). The inadequacy of the Oxonian meme underlay Kortlandt's choice not to use the term in the early 1980s in his treatment of the replicating units of language, viz. meanings with the propensity of nonconstructible sets in the intuitionist mathematical sense.

Pursuant to the discovery of the double helical structure of DNA in 1953, the coinage gene - by truncation from genetic - aided and abetted the popularisation of the 1976 coinage meme so that meme soon outcompeted all other coinages. The deficiency of the Oxonian conception of the unit of cultural evolution, however, necessitated either the redefinition or replacement of the term meme. In my view, the term's popularity and its interesting lineage made it more expedient to redefine the term rather than to coin yet another neologism. The Leiden definition brought the term back into line with the conception of earlier thinkers by redefining a meme as a neuroanatomica unit corresponding to a sign in the Saussurean sense, i.e., the neuronal correlate of a meaning along with the neuronal representations of its associated phonological form and grammatical manifestation.

In Leiden, a unit of imitation was termed a mime. In contrast to a meme, a mime does not as ably meet the criteria of fecundity, high-fidelity replication and longevity required to qualify as a successful life-sustaining replicator. With memes the competition between observable populations of patterns is more fierce than in the case of mimes. Meaning and language account for the difference between the behaviour of pre-linguistic mimes, e.g., the rice washing of Japanese macaques or the elaborate songs of whales, and the comportment of post-linguistic mimes, e.g., music, clothing fashions, dancing styles. In ethology, the term culture has come to be applied to complex learnt behaviours transmitted between conspecifics in numerous species other than our own. This usage is apt, but an essential difference remains between the semiotically enriched culture of our species and the mimetic culture of other species, which are not inhabited by a language organism. Other species lack memes in the Leiden sense of a Saussurean sign.

Mimes behave differently once they are awash in a sea of linguistic meanings with their multitudinous neuronal associations and interconnections. Our patterns of imitation as humans are more elaborate because our mimetic culture has been semiotically enriched and enmeshed with our inordinately more complex languagemediated or memetic culture. Yet the theme of Beethoven's 9th symphony none the less remains a mime, and is not a meme. Music is a paralinguistic phenomenon that is causally intimately connected with the evolutionary emergence of language, but music is not language.

Many people today use the word meme as just a trendy word for idea, and it has long been appreciated that ideas spread, and that some ideas spread more successfully than others. Perhaps most people can live quite happily without the meme concept. My use of the term meme in the Leiden sense, reiterated here, dates from 1983. My teacher Frederik Kortlandt, however, used to discourage my use of the term meme because of the inadequacy of the Oxford definition. He disputed the utility of using the term in my redefined sense on account of the availability of other terms, e.g., Saussurean sign, and he warned about the confusion that might arise from using the term in two competing definitions, i.e., sensu Lugdunensi vs. sensu Oxoniensi. Yet as I have shown above, the Leiden definition is more in keeping with the history of thought about cultural evolution. Moreover, the Leiden redefinition of the meme can heal the fuzziness which debilitates some of the burgeoning discourse on memetics.

Characteristically, meanings travel in packs within which a hierarchical structure obtains. As I have pointed out before, the idea that, for example, 'America is one nation, under God, with liberty and justice for all' is not a meme. This sentence is a syntactically articulate idea composed of a number of constituent lexical and grammatical memes, and this idea and its constituent parts are subject to Darwinian natural selection. The decomposability of units of function, such as words, phrases, sentences and narrative, is a central feature of linguistic phenomena and underscores the need for analysis to be conducted at the different levels of granularity traditionally distinguished in linguistics. The smallest structural units in language, viz. phonemes, are smaller than - though also sometimes equal in size to - the smallest functional units, viz. single morphemes and monomorphemic words.

In a strand of DNA, sets of individual base pairs together form the threenucleotide sequences known as codons, which each code for a specific amino acid. 
Even phonologically streamlined languages like Rotokas, spoken on Bougainville island, and Pirahã, spoken along the Maici river in Amazonia, have phoneme inventories greater than the four-letter alphabet of nucleotides which make up the genetic code, even though both languages have fewer phonemes than what Alfredo Trombetti reckoned to be il minimo di suoni che si possono con ogni probabilità attribuire alle più antiche fasi del linguaggio umano' (1905: 209).

Whilst the four nucleotides could perhaps be seen as the analogues of phonological features, the repertoire of 64 possible codons is of more or less the same size as an average phoneme inventory. So, are memes really the precise analogues of genes? Linguistic signs have the nature of non-constructible sets, and the reservoir of linguistic signs is potentially infinite in size. What precisely are genes? Are genes too non-constructible sets? Analogies can lead to muddled thinking if a conceit is overextended. We should not lose sight of the fact that semiotic entities are essentially different in nature and inherently different in their dynamics from macromolecules in numerous ways

Another useful way of thinking about the language-borne units of cultural evolution was proposed by Kortlandt in 2003. The units of meaning are neuronal configurations which behave like a group of ants in an anthill or like the termites of a termite colony. Ant foraging is perhaps a more apt model for the exploratory behaviour of linguistic meanings in the human brain. Anthills are characterised by intricate patterns of exploratory behaviour which give the appearance of being the outcome of a careful overall pathfinding strategy, but which in fact result from numerous relatively simple responses by individual ants to the availability of potential food supplies. Ants leaving the nest secrete trails of pheremones which they follow back to the nest. Ants who have found food secrete more volatile pheremones. Trails that are not reinforced often enough by pheremones tend to evaporate after a while. As a consequence, some ants regularly stray away from weak trails and wander off in a random fashion.

The connectivity of semiotic neuronal groups is likely to operate on the same exploratory principle as ant foraging. Such an exploratory mechanism may be an optimal way of finding targets in a complex environment. Neuronal groups are continually subject to modifications brought about by changes in the environment. At the same time, neuronal exploration establishes myriads of new linkages between neuronal groups. The opportunities for generating novel contingencies are thus constantly multiplied. The exploratory mechanism fulfils a physiological function that remains vital in a forever changing environment. Rather than meme, the term deme has been suggested by Kortlandt to denote a functionally coherent configuration of neuronal groups which constitute the neuroanatomical instantiation of a meaning.

Meanings that have colonised a human brain seek to reproduce through meaningful contacts. Just as an ant or termite that has strayed far afield may discover a new source of food, so too meanings find new conceptual havens from which to proliferate.
The dynamics of this process yields vast repertoires of linguistics meanings. During reproduction in the process of transfer from one host to another, a meaning is reduced and, as it were, stripped of its connotations and associations, which must be constructed anew in the brain of the new host. Just as a human is reduced to a haploid sperm cell in the process of reproduction, the isofunctional set of neuronal configurations constructed in the brain of a new host is unique and microanatomically specific to that individual. Just as the needs and prerogatives of an ant colony supersede those of the individual ant, language and linguistically mediated thought shape human societies and supersede the interests of the individual.

\section{The nature of the beast}

The beast in the brain is a complex organism in its own right and has a high degree of autonomy. We cannot change the grammatical structure of language or fundamentally change its lexicon by an act of will, even though we might be able to coin a new word or aid and abet the popularity of a turn of phrase. Language changes, but seldom because we want it to. We are inoculated with our native language in our infancy. Like any other life form, language consists of a self-replicating core. The units of this self-replicating core are the isofunctional neuronal correlates of signs in the sense of Ferdinand de Saussure, i.e., of meanings and of their associated phonological forms. So, is language a parasite or a mutualist? The architecture of language and the intricate dynamics of the relationship between the biological host and its semiotic symbiont make the answer a complex one.

Our species has overrun the planet. A conventional measure of success for a species is reproductive fitness, and ours has manifestly been enhanced by language, whilst at the same time language thrives through us. By this criterion, therefore, language is a mutualist symbiont. If language were to be a parasite, then why has it not led to the extinction or at least attrition of our species? As Kortlandt has darkly hinted in this context, time will tell. Moreover, he stresses that language is our own undoing even now, for throughout history and in each of our daily lives our most vexing problems derive from language.

Language remains largely impervious to the well-being of man, and it colours and even stunts the perceptive faculties of its hominid host. Certainly, from the perspective of language, human brains are tools for the reproduction of language. Our grey matter has been recruited for the propagation of linguistic signs through the relentless proliferation from host to host of isofunctional neural constructs. The idea that language exerts an unfavourable effect on perception itself and blinds us to reality is an old idea already espoused by Bertus Brouwer and Frederik van Eeden. Language shapes our conceptual reality, yet there is a complex relationship between language as such and 
language-borne ideas. Whether or not the capricious nature of non-constructible sets portends our doom as a species, two other issues are relevant to an understanding of how the relationship between language and man straddles the distinction between mutualism vs. parasitism.

One issue is whether or not language debilitates its hominid host. We humans are inoculated with language at birth. Language infests our brain and stays with us until we are entirely brain-dead. Our brains teem with linguistic signs, and each time a linguistic form with its associated meaning is activated in our brain, a Darwinian gen eration time has elapsed in terms of the neuronal group selection which characterises the rapid life cycle of linguistic signs. By analogy with biological models, it has been my contention that language itself is a mutualist, whereas not all meanings borne by language are mutualists.

As in any symbiotic relationship, models predict that categories of meaning which are vertically transmitted from the parent host to his or her infant offspring are more likely to be mutualistic in nature. Such are the grammatical categories of a language and much of the core vocabulary which is structural to a given language. These constellations of meaning construct our reality and shape our perceptions in pervasive and insidious ways. Yet by and large the grammatical and lexical core of the language acquired in infancy collectively enhances the reproductive fitness of the hominid host.

In contrast with language as such, categories of meaning borne by language that we acquire subsequently and that are readily transmitted horizontally from host to host within a single host generation are less likely to be beneficial. Whereas some linguistic signs may be highly salubrious, others may be lethal to the host and devastating to the host community at large. Jihad, racial purity, proletariat, religious tenets and various other brands of political correctness are obvious examples of pathological ideas, but in fact all horizontally transmitted thoughts are potentially dangerous and parasitic. We live the myths and ideas that impinge upon us and that wash across our societies. Religion is a disease of language. What else does Symbiotic Theory enable us to predict? Symbiosism predicts God, hypocrisy, suicide, ideologies, rites and rituals, sports, the supernatural, theatre, crusades and jihads and numerous other cultural and psychological phenomena, both delightful and baneful, that result from language and make us uniquely human, marking our species as an anomaly in the biological world.

The distinction between the grammatical and lexical core of a language with which an infant human is inoculated and all the language-borne notions that the person acquires later in life is no sharp dichotomy but a fuzzy gradient. Applied to the language organism, the point of the distinction between the vertical and horizontal propagation of linguistic signs from host to host is merely that language-borne notions of reality such as infidel, Ahnenpaß or kosher will have a greater likelihood of being malevolent than meanings such as the present perfect tense, the zero morpheme for singular number in nouns, or lexical items such as mother, hungry and water. Meanings and syntactically articulated constellations of meanings may be wholesome, indifferent to the well-being of the host, or debilitating. This can only be judged by the effects of linguistic signs, not by their appeal, which is no more than an index of their contagiousness and no indication of their truthfulness.

\section{From symbiosism to symbiomism}

'When I use a word,' Humpty Dumpty said, in rather a scornful tone, 'it means just what I choose it to mean - neither more nor less.' 'The question is', said Alice, 'whether you can make words mean so many different things.' 'The question is', said Humpty Dumpty, 'which is to be master - that's all.'

A second issue is whether we are at the mercy of language. In his seminal article on the language parasite, Kortlandt stated: 'The view of language as a tool of the human species is less well-founded than its converse. The question is, in Humpty Dumpty's words, which is to be master' (1985: 478). I agree that we are at the mercy of language, but just who are we? Certainly, we are not just the hominid host, as the sad example of feral children teaches us (Ball 1880; Burnett 1784; de la Condamine 1755; Dresserus 1577; Itard 1801, 1894; Mason 1942; Singh \& Zingg 1942; Sleeman 1858; Squires 1927; Rauber 1885). These soulless children are not fully human, though they are no doubt entirely hominid.

We are not just flesh and blood, we are what we believe. We are symbiomes of body and soul. Our species constitutes a unique type of symbiome in the natural world because of the singular and still quite primitive nature of the semiotic symbiont, language. The dual biological and semiotic mechanics of the symbiome are the key to understanding human mental health. Symbiomism is the school of philosophy which understands our human identity as symbiomes of a biological and a semiotic symbiont. Man is both the hominid host and the language that dwells in his brain and that mediates much of his thinking. Good health is the state in which both constituent symbionts are healthy and abide in some sort of happy equilibrium.

Our body is that of a particular variety of great ape with all its social primate propensities, equipped with a brain which has grown bloated in a long process of coevolution with language. Our soul is the language organism which resides within our skull along with everything inside our brain that is mediated by language. The moment on the 5th of April 1887, when suddenly and heart-rendingly 'the mystery of language was revealed to' her, Helen Keller would subsequently describe as her 'soul's sudden awakening' (1905: 23). We are incomplete without language. The colonisation of an australopithecine brain by language was the symbiogenesis that yielded the first human beings.

The controversy about parasitism vs. mutualism boils down to the question of what makes us human. On the matter of our identity as a species, Wilhelm von Humbold 
observed: 'Der Mensch ist nur Mensch durch Sprache' (1822: 244). The issue of whether the language organism or its hominid host has the upper hand begs the question of our very identity. When Humpty Dumpty asks who is to be master, how much does it really matter? If it feels good to live in a linguistically constructed reality, can this opium really be so bad for us? Of course, whenever we are driven to immolate ourselves for some abstract ideal, or to kill ourselves and murder others for the sake of some belief system, then this question becomes more pressing.

We are as much our essentially linguistic soul as we are its corporeal hominid host. Being healthy involves keeping both components of a symbiome happy. Our brain houses a consciousness which sustains the illusion of a thinking self with a free will. In reality, our feelings, thoughts, yearnings and behaviour are the outcome of the jostle and interplay of the biological propensities and lust for creature comforts of the human host in symbiotic association with a capricious linguistic symbiont which serves as the vehicle for the ideas waging war within us. So when we speak, who is doing the talking?

\section{References}

Ball, Valentine. 1880. Jungle Life in India, or the Journeys and Journals of an Indian Geologist. London: T. de la Rue.

de Bary, Heinrich Anton. 1879. Die Erscheinung der Symbiose: Vortrag gehalten auf der Versammlung Deutscher Naturforscher und Aerzte zu Cassel. Straßburg: Verlag von Karl J. Trübner.

van Beneden, Pierre Joseph. 1876. Die Schmarotzer des Thierreichs. Leipzig: F.A. Brockhaus.

Blackmore, Susan. 1999. The Meme Machine. Oxford: Oxford University Press.

Blum, Harold F. 1963. 'On the origin and evolution of human culture', American Scientist, 51 (1): 32-47.

Burhoe, Ralph W. 1967. 'Five steps in the evolution of man's knowledge of good and evil', Zygon, 2: 77-96.

Burnett, James [Lord Monboddo]. 1784. Antient Metaphysics, Containing the History and Philosophy of Meng, Vol. III. Edinburgh: J. Balfour.

Changeux, Jean-Pierre. 1983. L'homme neuronal. Paris: Librairie Arthème Fayard.

Cloak, FT. 1975. 'Is cultural ethology possible', Human Ecology, 3 (3): 161-182.

de la Condamine, Charles-Marie. 1755. Histoire d'une jeune fille sauvage, trouvée dans les bois à lâge de dix ans. Paris: Madame Hecquet.

Darwin, Charles Robert. 1871. The Descent of Man and Selection in Relation to Sex (2 vols.). London: John Murray

Dawkins, Richard. 1976. The Selfish Gene. Oxford: Oxford University Press.

Dawkins, Richard. 1989. The Selfish Gene (new edition). Oxford: Oxford University Press.

Dresserus, Matthaeus. 1577. De Disciplina Nova et Veteri: Tam Domestica, quàm scholastica; Ad consolandum erudiendumq[ue] parentes, praeceptores, ac liberos. Basel: Ex Officina Oporiniana. van Driem, George. 2001a. Taal en Taalwetenschap. Leiden: Research School of Asian, African and Amerindian Studies CNws.

van Driem, George. 2001b. Languages of the Himalayas: An Ethnolinguistic Handbook of the Greater Himalayan Region with an Introduction to the Symbiotic Theory of Language (2 vols.). Leiden: Brill.

van Driem, George. 2003. 'The language organism: The Leiden theory of language evolution', in Jiří Mírovský, Anna Kotěšovcová and Eva Hajičová, Eds, Proceedings of the XVIIth International Congress of Linguists, Prague, July 24-29, 2003. Prague: Matfyzpress vydavatelství Matematicko-fyzikální fakulty Univerzity Karlovy.

van Driem, George. 2004. 'Language as organism: A brief introduction to the Leiden theory of language evolution', pp. 1-9 in Ying-chin Lin, Fang-min Hsu, Chun-chih Lee, Jackson T.-S. Sun, Hsiu-fang Yang \& Dah-ah Ho, Eds, Studies on Sino-Tibetan Languages: Papers in Honor of Professor Hwang-cherng Gong on his Seventieth Birthday (Language and Linguistics Monor of Professor Hwang-cherng Gong on his Seventieth Birthday (Language

van Driem, George. 2005. 'The language organism: The Leiden theory of language evolution', pp. 331-340 in James W. Minett \& William S-Y. Wang, Eds, Language Acquisition, Change and Emergence: Essays in Evolutionary Linguistics. Hong Kong: City University of Hong Kong Press.

van Driem, George. forthcoming. The Language Organism.

Edelman, Gerald M. 1987. Neural Darwinism: The Theory of Neuronal Group Selection. New York: Basic Books.

Famintsyn, Andrej Sergeevič. 1889. Beitrag zur Symbiose von Algen und Thieren, Mémoires de l'Académie Impériale des Sciences de St. Pétersbourg, xxxvi (16): 1-36.

Famintsyn, Andrej Sergeevič. 1893. 'O sud'bě zeren" xlorofilla v" semenax" i prorostkax"', Trudy Botaničeskoj Laboratorii Imperatorskoj Akademii Nauk', 5: 1-16.

Famintsyn, Andrej Sergeevič. 1907. 'O roli simbioza v" èvoljucii organizmov"', Trudy Botaničeskoj Laboratorii Imperatorskoj Akademii Nauk", 9: 1-14.

Frank, Albert Bernard. 1885. 'Ueber die auf Wurzelsymbiose beruhende Ernährung gewisser Bäume durch unterirdische Pilze', Berichte der Deutschen Botanischen Gesellschaft, III $128-145$.

Hebb, Donald Olding. 1949. The Organization of Behavior: A Neurophysiological Theory. New York: John Wiley \& Sons.

Henry, Sidney Mark. 1966, 1967. Symbiosis (two vols.). New York and London: Academic Press. Hoagland, Hudson. 1964. 'Science and the new humanism: Science and purpose are related to man's unique ability as an ethical animal to control his evolution', Science, 143 (3602): $111-114$.

Hugo, Victor. 1856. Les contemplations (2 vols.). Bruxelles: Lebegue.

von Humboldt, Wilhelm. 1812. 'Ankündigung einer Schriftüber die vaskischeSprache und Nation, nebst Angabe des Gesichtpunctes und Inhalt derselben', pp. 1-8 [i.e., eight numbered pages following p. 472] in F. Delbrück, C.G.A. Erfurdt, J.F. Herbart, K.D. Hülmann, J.F. Krause \& J.S. Vater, Eds, Königsberger Archiv für Philosophie, Theologie, Sprachkunde unde Geschichte. Königsberg: Friedrich Nicolovius.

von Humboldt, Wilhelm. 1822. 'Ueber das vergleichende Sprachstudium in Beziehung auf die verschiedenen Epochen der Sprachentwicklung', Abhandlungen der Königlichen Preussischen Akademie der Wissenschaften, historisch-philosophische Klasse, aus den Jahren 1820 und 1821: 239-260 
Huxley, Julian S. 1962. 'Evolution: biological and human', Nature, 196 (4851, 20 October 1961): 203-204.

Itard, Jean-Marc Gaspard. 1801 [i.e., an X]. De l'éducation d'un homme sauvage, ou Des premiers développements physiques et moraux du jeune sauvage de l'Aveyron. Paris: Goujon fils.

Itard, Jean-Marc-Gaspard. 1894 [posthumous]. Rapports et mémoires sur le sauvage de l'Aveyron, l'idiotie et la surdi-mutité. Paris: Félix Alcan.

Keller, Helen Adams. 1905. The Story of My Life. New York: Doubleday, Page \& Company.

Kortlandt, Frederik Herman Henri. 1985. 'A parasitological view of non-constructible sets' pp. 477-483 in Ursula Pieper and Gerhard Stickel, Eds, Studia linguistica diachronica et synchronica: Werner Winter sexagenario anno MCмLхxхпI gratis animis ab eius collegis, amicis discipulisque oblata. Berlin: Mouton de Gruyter.

Kortlandt, Frederik Herman Henri. 1998. 'Syntax and semantics in the history of Chinese' Journal of Intercultural Studies, 5: 167-176.

Kortlandt, Frederik Herman Henri. 2003. 'The origin and nature of the linguistic parasite' pp. 241-244 in Brigitte Bauer \& Georges-Jean Pinault, Eds, Language in Time and Space: A Festschrift for Werner Winter on the Occasion of his 80th Birthday. Berlin: Mouton Gruyter.

Krause, Gottlob Adolf. 1885. 'Die Stellung des Temne innerhalb der Bantu-Sprachen', Zeitschrift für afrikanische und oceanische Sprachen, mit besonderer Berücksichtigung der Deutschen Kolonien, I: 250-267.

Kuhn, Thomas S. 1962. The Structure of Scientific Revolutions (International Encyclopedia of Unified Science, Foundations of the Unity of Science, Volume II, Number 2). Chicago: University of Chicago Press.

Kuhn, Thomas S. 1977. The Essential Tension: Selected Studies in Scientific Tradition and Change. Chicago: University of Chicago Press.

Laurent, John. 1999. 'A note on the origin of "memes"/"mnemes", Journal of Memetics, 3 (1) 20-21.

Maeterlinck, Maurice Polydore Marie Bernard. 1927. The Life of the White Ant. London: George Allen and Unwin.

Margulis, Lynn, and Karlene V. Schultz. 1998. Five Kingdoms: An Illustrated Guide to the Phyla of Life on Earth (third edition). New York: W.H. Freeman \& Company

Mason, Marie K. 1942. 'Learning to speak after six and one-half years of silence', Journal of Speech Disorders, 7: 295-304.

de Maupertuis, Pierre Louis Moreau. 1756. 'Dissertation sur les différents moyens dont les hommes se sont servis pour exprimer leurs idées', pp. 435-468, vol. III in Euvres (nouvelle édition corrigée et augmentée, 4 vols.). Lyon: Jean-Marie Bruyset.

Mereschkowsky, Constantin [i.e., Konstantin Sergeevič Mereškovskij]. 1905. 'Über Natur und Ursprung der Chromatophoren im Pflanzenreiche', Biologisches Centralblatt, xxv (18): 593-604.

Mereškovskij, Konstantin Sergeevič. 1909a. Teorija dvux" plazm" kak" osnova simbiogenezisa, novogo učenija o proisxoždenii organizmov". Kazan': Tipografija Imperatorskago Kazan’skago Universiteta [published the same year in instalments in German translation as (1909b)].

Mereschkowsky, Constantin [i.e., Konstantin Sergeevič Mereškovskij]. 1909b. 'Theorie der zwe Plasmaarten als Grundlage der Symbiogenesis, einer neuen Lehre von der Entstehung der Organismen', Biologisches Centralblatt, $\operatorname{xxx}(8)$ : 278-288, xxx (9): 289-303, $\operatorname{xxx}(10)$ : $321-347$, and $x \times x$ (11): 353-367.
Rauber, August. 1885. Homo sapiens ferus, oder die Zustände der Verwilderten und ihre Bedeutung für Wissenschaft, Politik und Schule. Biologische Untersuchung von Dr. A. Rauber. Leipzig: Denicke.

Rodríguez-Ezpeleta, Naiara, Henner Brinkmann, Suzanne C. Burey, Béatrice Roure, Gertraud Burger, Wolfgang Löffelhardt, Hans J. Bohnert, Hervé Philippe \& B. Franz Lang. 2005. 'Monophyly of primary photosynthetic eukaryotes: Green plants, red algae and glaucophytes', Current Biology, 15: 1325-1330

Salverda, Reinier. 1998. 'Is language a virus? Reflections on the use of biological metaphors in the study of language', pp. 191-209 in Mark Janse and An Verlinden, Eds, Productivity and Creativity. Studies in General and Descriptive Linguistics in Honor of E.M. Uhlenbeck. Berlin: Mouton de Gruyter.

Salverda, Reinier. 2003. Letter to the Editor, New Scientist (1 February 2003), 2380: 25.

Schatzmann, Jürg. 1968. Richard Semon (1859-1918) und seine Mnemetheorie. Zürich: Juris Druck Verlag.

Schimper, Andreas Franz Wilhelm. 1883. 'Ueber die Entwickelung der Chlorophyllkörner und Farbkörper', Flora oder Allgemeine Botanische Zeitung, 41 (7): 105-114, 121-131, 137-146, $153-162$.

von Schlegel, Friedrich. 1808. Ueber die Sprache und Weisheit der Indier: Ein Beitrag zur Begruendung der Alterthumskunde, nebst metrischen Uebersetzungen indischer Gedichte. Heidelberg: Mohr und Zimmer.

Schleicher, August. 1863. Die Darwinsche Theorie und die Sprachwissenschaft: Offenes Sendschreiben an Herrn Dr. Ernst Häckel, a.o. Professor der Zoologie und Direktor des zoologischen Museums an der Universität Jena. Weimar: Böhlau.

Schmitz, Friedrich Karl Johann. 1882. Die Chromatophoren der Algen. Vergleichende Untersuchungen über Bau und Entwicklung der Chlorophyllkörper und der analogen Farbstoffkörper der Algen. Bonn: Verlag von Max Cohen \& Sohn (Fr. Cohen)

Schuchardt, Hugo. 1919a. 'Sprachursprung. I' (vorgelegt am 17. Juli 1919), Sitzungsberichte der Preussischen Akademie der Wissenschaften, xuII: 716-720.

Schuchardt, Hugo. 1919b. 'Sprachursprung. I' (vorgelegt am 30. Oktober 1919), Sitzungsberichte der Preussischen Akademie der Wissenschaften, xuI: 863-869.

Semon, Richard Wolfgang. 1911 [1904] Die Mneme als erhaltendes Prinzip im Wechsel des organischen Lebens (dritte Auflage). Leipzig: Wilhelm Engelmann.

Semon, Richard Wolfgang. 1922 [1909]. Die mnemischen Empfindungen in ihren Beziehungen zu den Originalempfindungen (zweite Auflage) Leipzig: Wilhelm Engelmann.

Singh, Joseph Amrito Lal \& Robert M. Zingg. 1942. Wolf Children and Feral Man. New York Harper.

Sleeman, William Henry. 1858. A Journey through the kingdom of Oude in 1849-1850 by Direction of the Right Honourable the Earl of Dalhousie, Governor-General, with Private Correspondence Relative to the Annexation of Oude to British India. London, R. Bentley.

Squires, Paul. 1927. '"Wolf children" of India, American Journal of Psychology, 38: 313-315.

Swanson, Carl P. 1973. The Natural History of Man. Englewood Cliffs, New Jersey: Prentice-Hall. Trombetti, Alfredo. 1905. L'unità dorigine del linguaggio. Bologna: Libreria Treves di Luigi Beltrami.

Trombetti, Alfredo. 1925. Le origini della lingua basca (Memoria presentata alla Reale Accademi delle Scienze dell'Istituto di Bologna nella Sessione del 24 Novembre 1923). Bologna: Cooperativa Tipografica Azzoguidi. 
Ujhelyi, Mária. 1998. 'Long-call structure in apes as a possible precursor for language', pp. 177-189 in James R. Hurford, Michael Studdert-Kennedy \& Christ Knight, Eds, Evolution of Language: Social and Cognitive Bases. Cambridge: Cambridge University Press.

Welby [i.e., Welby-Gregory], Victoria Alexandrina Maria Louisa Stuart-Wortley. 1896. 'Sense, meaning and interpretation,' Mind, v: 24-37, 186-202.

White, Leslie A. 1959. 'The concept of culture', American Anthropologist, 61: 227-251.

Wiedenhof, Jeroen Maarten. 1996. 'Nexus and the birth of syntax', Acta Linguistica Hafniensia, 28: $139-150$.

\section{Some speculations on the evolution of language, and on the language of evolution}

Paul Whitehouse

London, England

The need for languages to be complete systems suggests that language evolution will be episodic rather than gradual, with periods of stability punctuated by periods of innovation. The example of nicaraguan sign language suggests that such developmental phases can be very rapid. Rapid evolution can create genetic bottlenecks. The differentiation between Homo sapiens and $\mathrm{H}$. erectus was probably the result of a genetic bottleneck arising from the invention of language by part of the $\mathrm{H}$. erectus population. This occurred in Africa, probably between 200 and 100 kyrs BP. The possession of fully complex language by every living human community suggests that it had already been developed by our H. Sapiens ancestors before they left Africa. The possession of complex language has allowed humans to participate in their own evolution in ways impossible for other animals.

\section{Stability versus innovation}

Nineteenth century linguists were content to classify languages as more or less primitive according to their typology, but nowadays - not least because of the racist assumptions that underpinned such classifications - linguists treat all languages as being at the same stage of development, and avoid the suggestion that some extant language might be in any way "primitive". Nevertheless, if human language did not come into existence fully formed, it must have undergone some sort of development process, passing through stages to which the term "primitive" would apply. If so, what might such "primitive" languages have looked like?

The obvious question is: primitive compared to what? What characterises the stage we consider all modern languages to have reached? One thing they all have in common is that they are all complete systems. They are able to express every relationship of person, time and place that might reasonably arise, and have some means, however clumsy, of resolving those ambiguities that the language may contain. This accounts for a second feature they share in common, which is that they are all stable. The universality 